\title{
Composition of the electrocautery smoke: integrative literature review
}

\section{Composição da fumaça produzida pelo bisturi elétrico: revisão integrativa da literatura Composición del humo producido por el bisturí eléctrico: revisión integradora de la literatura}

Cibele Cristina Tramontini ${ }^{1,2}$, Cristina Maria Galvão ${ }^{1}$, Caroline Vieira Claudio ${ }^{3}$, Renata Perfeito Ribeiro², Júlia Trevisan Martins ${ }^{2}$

\section{How to cite this article:}

Tramontini CC, Galvão CM, Claudio CV, Ribeiro RP, Martins JT. Composition of the electrocautery smoke: integrative literature review. Rev Esc Enferm USP. 2016;50(1):144-53. DOI: http://dx.doi.org/10.1590/S0080-623420160000100019

${ }^{1}$ Universidade de São Paulo, Escola de Enfermagem de Ribeirão Preto, SP, Brazil.

${ }^{2}$ Universidade Estadual de Londrina, Londrina, PR, Brazil.

${ }^{3}$ Universidade Estadual de Londrina, Programa de Pós-Graduação em Enfermagem, Londrina, PR, Brazil.

\begin{abstract}
Objective: To identify the composition of the smoke produced by electrocautery use during surgery. Method: Integrative review with search for primary studies conducted in the databases of the US National Library of Medicine National Institutes of Health, Cumulative Index to Nursing and Allied Health Literature, and Latin American and Caribbean Health Sciences, covering the studies published between 2004 and 2014. Results: The final sample consisted of 14 studies grouped into three categories, namely; polycyclic aromatic hydrocarbons, volatile compounds and volatile organic compounds. Conclusion: There is scientific evidence that electrocautery smoke has volatile toxic, carcinogenic and mutagenic compounds, and its inhalation constitutes a potential chemical risk to the health of workers involved in surgeries.
\end{abstract}

\section{DESCRIPTORS}

Occupational Exposure; Occupational Risks; Occupational Health; Electrosurgery; Smoke; Review. 


\section{INTRODUCTION}

The surgical center can be considered one of the most complex units of the hospital for its specialty and the constant presence of stress and health risk, both for patients who are subject to surgical intervention, as to employees who work in the multidisciplinary team.

Energy generating equipments such as the electrocautery are widely used in the operating room. The use of electrocautery decreases intraoperative bleeding and improves visibility during surgery ${ }^{(1)}$, but the smoke produced because of its use can harm the health of workers.

The smoke produced by the use of electrocautery is formed by gas chemical compounds (gaseous phase) and by components of particles (particulate phase) that can trigger harmful, local or systemic, reversible or irreversible effects in people using this equipment ${ }^{(2)}$.

With regard to the chemical composition of electrocautery smoke, it may contain polycyclic aromatic hydrocarbons $(\mathrm{PAH})^{(3)}$, volatile organic compounds $(\mathrm{VOC})^{(4)}$, carbon monoxide $(\mathrm{CO})^{(5)}$, among others. These chemicals may trigger genetic mutations ${ }^{(6)}$ and cancer $^{(7)}$ in the human body.

In addition to mutation and cancer, the particles in the electrocautery smoke can be inhaled and retained in the workers' respiratory tract, causing various respiratory signs and symptoms, including foreign body sensation in the throat, burning pharyngeal, nausea and nasal congestion ${ }^{(1)}$. It can also cause headache and eye irritation ${ }^{(2)}$.

It is estimated that each year 500,000 workers in the United States - including surgeons, nurses, anesthesiologists and surgical scrub nurses - are exposed to the smoke produced by the use of electrocautery ${ }^{(8)}$.

Electrocautery smoke may be removed from the atmosphere through a ventilation system such an exhaust fan, and adequate ventilation, which are essential in operating rooms ${ }^{(9-10)}$. It is also possible to reduce risks to workers' health in the operating room by using the N-95 mask ${ }^{(11)}$.

The N95 mask, a respiratory protective equipment, provides filtration of at least $95 \%$ of aerosols, gases and fumes ${ }^{(11)}$, including electrocautery smoke ${ }^{(11-13)}$, thus contributing to a healthier work environment.

Although there are recommendations to reduce the risk of ectrocautery smoke by removing it through proper ventilation, in practice there is little care with removing it from the operating room environment during surgical procedures ${ }^{(14)}$.
Given the exposed, arises the following research question: 'What is the scientific evidence about the composition of the electrocautery smoke produced during surgery?'. To answer this question, this study aimed to identify the composition of the electrocautery smoke produced during surgery.

This study stands out for its unparalleled importance, given the scarcity of research on this issue. Understanding the health risks related to inhalation of electrocautery smoke is also of fundamental importance for the health promotion of surgical team workers, and to prevent injuries and illnesses.

\section{METHOD}

This is an integrative literature review that enables the incorporation of clinical practice evidences ${ }^{(15)}$. The development of this review followed six stages: preparation of the research question, sampling or literature search for primary studies, data extraction, assessment of the included primary studies, analysis and synthesis of the results, and presentation of the review ${ }^{(16)}$.

The literature search was organized according to the criteria and manuals for each database. The following controlled descriptors were used (Medical Subject Headings and Descriptors in Health Sciences) - Electrosurgery, Electrocoagulation, General Surgery, Occupational Exposure, Surgical Specialties and Laser Therapy, and the uncontrolled descriptors (keywords) - Monopolar Electrosurgery, Bipolar Electrosurgery, Monopolar Bipolar Electrosurgery, Electrocautery, Monopolar Electrocautery, Bipolar Electrocautery, Surgical Smoke, Smoke Surgical, Surgical Smoke Plume, Electrosurgery Smoke, Electrocautery Smoke, Surgery, Surgery Operative, Occupational Hazards, Occupational Health and Occupational Risk, combined with Boolean operators (AND e OR).

The search using the aforementioned descriptors was carried out between September and October 2014 in the databases of the US National Library of Medicine National Institutes of Health (PubMed), Cumulative Index to Nursing and Allied Health Literature (CINAHL), and Latin American and Caribbean Health Sciences (LILACS).

Another strategy used was the manual search for bibliographic references in the databases of the selected primary studies. The descriptors were combined in different ways to ensure an extensive search. Chart 1 shows the combinations.

Chart 1 - Combinations of descriptors in the databases of PubMed, CINAHL and LILACS (2004-2014) - Londrina, PR, Brazil, 2015.

\begin{tabular}{|c|l|}
\hline Database & \multicolumn{1}{c|}{ Combinations } \\
\hline \multirow{5}{*}{ PubMed } & $\begin{array}{l}\text { Electrosurgery OR Bipolar electrosurgery OR Monopolar electrosurgery OR Monopolar bipolar electrosurgery OR } \\
\text { Electrocautery OR Monopolar electrocautery OR Bipolar electrocautery AND Surgery AND Occupational hazards } \\
\text { OR Occupational exposure OR Occupational health OR Occupational risk AND Surgical smoke }\end{array}$ \\
\cline { 2 - 3 } & $\begin{array}{l}\text { Electrosurgery OR Bipolar electrosurgery OR Monopolar electrosurgery OR Monopolar bipolar electrosurgery OR } \\
\text { Electrocautery OR Monopolar electrocautery OR Bipolar electrocautery AND Surgery AND Occupational hazards } \\
\text { OR Occupational exposure OR Occupational health OR Occupational risk AND Surgical smoke plume }\end{array}$ \\
\hline
\end{tabular}


...continuation

\begin{tabular}{|c|l|}
\hline \multicolumn{1}{|c|}{ Database } & \multicolumn{1}{c|}{ Combinations } \\
\hline \multirow{5}{*}{ PubMed } & $\begin{array}{l}\text { Electrosurgery OR Bipolar electrosurgery OR Monopolar electrosurgery OR Monopolar bipolar electrosurgery OR } \\
\text { Electrocautery OR Monopolar electrocautery OR Bipolar electrocautery AND Surgery AND Occupational hazards } \\
\text { OR Occupational exposure OR Occupational health OR Occupational risk AND Electrosurgery smoke }\end{array}$ \\
\cline { 2 - 3 } & $\begin{array}{l}\text { Electrosurgery OR Bipolar electrosurgery OR Monopolar electrosurgery OR Monopolar bipolar electrosurgery OR } \\
\text { Electrocautery OR Monopolar electrocautery OR Bipolar electrocautery AND Surgery AND Occupational hazards } \\
\text { OR Occupational exposure OR Occupational health OR occupational risk AND Electrocautery smoke }\end{array}$ \\
\hline \multirow{5}{*}{ CINAHL } & $\begin{array}{l}\text { Occupational Exposure OR Occupational hazards AND Electrocoagulation AND Smoke surgical AND Surgery } \\
\text { operative }\end{array}$ \\
\cline { 2 - 3 } & Occupational Exposure OR Occupational hazards AND Electrosurgery AND Smoke surgical AND Surgery operative \\
\cline { 2 - 3 } & Occupational Exposure OR Occupational hazards AND Electrocautery AND Smoke surgical AND Surgery operative \\
\hline \multirow{3}{*}{ LILACS } & Cirurgia Geral OR Especialidades Cirúrgicas AND Terapia a Laser \\
\cline { 2 - 3 } & Cirurgia Geral OR Especialidades Cirúrgicas AND Eletrocoagulação \\
\cline { 2 - 3 } & Cirurgia Geral OR Especialidades Cirúrgicas AND Eletrocirurgia \\
\hline
\end{tabular}

The inclusion criteria for the primary studies were those addressing the presence of chemical compounds in the smoke produced by electrocautery use, published between January 2004 and August 2014 and with the following classifications: randomized controlled clinical trial, clinical trial without randomization, cohort study, case-control study, quasi-experimental studies, non-experimental/crosssectional studies, studies developed with human beings; and published in Portuguese, English and Spanish. Therefore, the evidence levels 2, 3, 4 and 6 were considered ${ }^{(17)}$. The established exclusion criteria were studies addressing the presence of bioaerosols (bacteria and viruses) in the electrocautery smoke.

Note that the evidence levels vary $1-7$, as follows: level 1 - meta-analysis or systematic reviews; level 2 - randomized controlled clinical trial; level 3 - clinical trial without randomization; level 4 - cohort and case-control studies; level 5 - systematic reviews of descriptive and qualitative studies; level 6 - descriptive or qualitative studies; and level 7 - expert opinion ${ }^{(17)}$.

The flowchart (Figure 1) describes the identification route, selection and inclusion of selected primary studies according to the electronic database consulted.

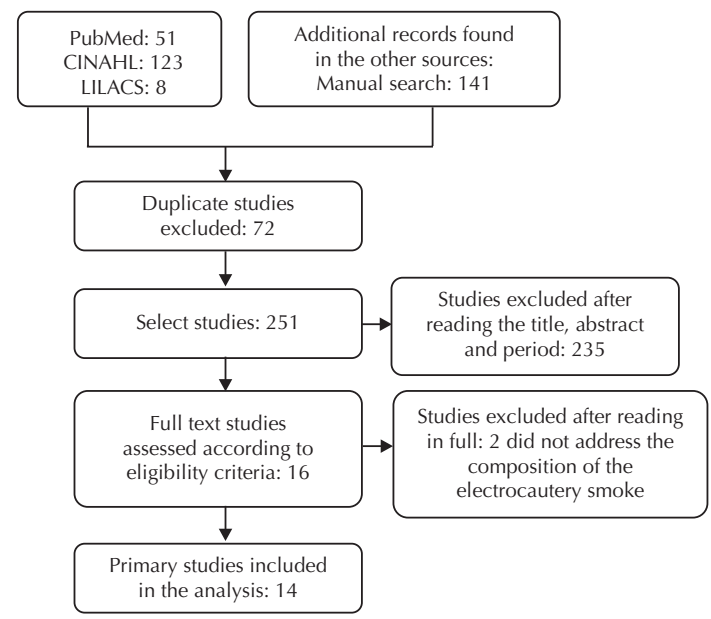

Figure 1 - Flowchart of identification, selection and inclusion of integrative review studies - Londrina, PR, Brazil, 2015.
The selection process and the study agreement method were developed by two expert reviewers independently, who selected the studies according to the eligibility and inclusion criteria. In case of disagreement, a third reviewer was consulted.

An adapted instrument of data collection proposed and validated by nursing research authors was used for the data extraction of the sample of selected primary studies ${ }^{(18)}$. This instrument includes identification of the article, year and place of study, methodological characteristics, assessment of methodological rigor, level of evidence, type of surgery, surgical time, method and analysis of collection, and type of the chemical compound found in the electrocautery smoke.

The evaluation of the selected types of studies was based on the concepts of scientific methodology scholars ${ }^{(19)}$, who classify the studies into two types: observational or clinical trial; the observational studies, in turn, are divided into cohort, cross-sectional and case-control.

Data analysis was performed in a descriptive way, emphasizing the types and occupational levels of the chemical compounds found in each study, and drawing comparisons between them, highlighting the differences and similarities.

There was no funding for the study, neither any conflict of interest in the conduction of this integrative literature review.

\section{RESULTS}

Of the 14 selected primary studies, one (7.1\%) was published in 2004; two (14.3\%) in 2007; one (7.1\%) in 2009; two $(14.3 \%)$ in 2010 ; one $(7.1 \%)$ in 2011 ; three $(21.4 \%)$ in 2012; one (7.1\%) in 2013; and three (21.4\%) in 2014.

As for the origin of the studies, all were published in English and in international journals, showing the scarcity of studies published in Brazilian journals. It was identified that the authors of the studies belong to departments of surgery, general surgery, public health, occupational health, and urology.

Regarding the location of studies, the majority $(28.5 \%)$ was held in South Korea. Locations were not reported in three studies (21.4\%).

In relation to design, they were all observational studies of descriptive type ${ }^{(19)}$, with quantitative approach, representing level 6 of scientific evidence ${ }^{(17)}$. 
Among the 14 studies selected and included in this integrative literature review, Chart 2 shows a summary of the primary studies according to title, year, study location, design and level of scientific evidence.

Chart 2 - Summary of the primary studies according to title, year, study location, design and level of evidence (2004-2014) - Londrina, PR, Brazil, 2015

\begin{tabular}{|c|c|c|c|c|c|}
\hline Study & Title & Year & Study location & Design & $\begin{array}{l}\text { Level of } \\
\text { evidence }\end{array}$ \\
\hline E1 & $\begin{array}{l}\text { Cancer risk of incremental exposure to polycyclic } \\
\text { aromatic hydrocarbons in electrocautery smoke for } \\
\text { mastectomy personnel }{ }^{(3)}\end{array}$ & 2014 & $\begin{array}{l}\text { Changhua, } \\
\text { Taiwan }\end{array}$ & $\begin{array}{l}\text { Observational/ } \\
\text { cross-sectional }\end{array}$ & 6 \\
\hline E2 & $\begin{array}{l}\text { Polycyclic aromatic hydrocarbons in electrocautery } \\
\text { smoke during peritonectomy procedures }\end{array}$ & 2012 & Uppsala, Sweden & $\begin{array}{l}\text { Observational/ } \\
\text { cross-sectional }\end{array}$ & 6 \\
\hline E3 & $\begin{array}{l}\text { Quantitative chemical analysis of surgical smoke } \\
\text { generated during laparoscopic surgery with a vessel- } \\
\text { sealing device }^{(5)}\end{array}$ & 2014 & $\begin{array}{l}\text { Zurich, } \\
\text { Switzerland }\end{array}$ & $\begin{array}{l}\text { Observational/ } \\
\text { cross-sectional }\end{array}$ & 6 \\
\hline E4 & $\begin{array}{l}\text { A single-blind controlled study of electrocautery } \\
\text { and ultrasonic scalpel smoke plumes in laparoscopic } \\
\text { surgery }\end{array}$ & 2012 & $\begin{array}{l}\text { Scotland, United } \\
\quad \text { Kingdom }\end{array}$ & $\begin{array}{l}\text { Observational/ } \\
\text { cross-sectional }\end{array}$ & 6 \\
\hline E5 & $\begin{array}{l}\text { Surgical smoke may be a biohazard to surgeons } \\
\text { performing laparoscopic surgery }\end{array}$ & 2014 & $\begin{array}{l}\text { Daegu, South } \\
\text { Korea }\end{array}$ & $\begin{array}{l}\text { Observational/ } \\
\text { cross-sectional }\end{array}$ & 6 \\
\hline E6 & $\begin{array}{l}\text { Comparative safety analysis of surgical smoke from } \\
\text { transurethral resection of the bladder tumors and } \\
\text { transurethral resection of the prostate }\end{array}$ & 2013 & $\begin{array}{l}\text { Jeonju, South } \\
\text { Korea }\end{array}$ & $\begin{array}{l}\text { Observational/ } \\
\text { cross-sectional }\end{array}$ & 6 \\
\hline E7 & $\begin{array}{l}\text { A novel inspection protocol to detect volatile } \\
\text { compounds in breast surgery electrocautery smoke }{ }^{(23)}\end{array}$ & 2010 & Taiwan & $\begin{array}{l}\text { Observational/ } \\
\text { cross-sectional }\end{array}$ & 6 \\
\hline E8 & $\begin{array}{l}\text { Composition of volatile organic compounds in } \\
\text { diathermy plume as detected by selected ion flow } \\
\text { tube mass spectrometry }\end{array}$ & 2007 & Unreported & $\begin{array}{l}\text { Observational/ } \\
\text { cross-sectional }\end{array}$ & 6 \\
\hline E9 & $\begin{array}{l}\text { Comparison of harmful gases produced during } \\
\text { greenlight high-performance system laser } \\
\text { prostatectomy and transurethral resection of the } \\
\text { prostate }^{(25)}\end{array}$ & 2012 & $\begin{array}{l}\text { Jeonju, South } \\
\text { Korea }\end{array}$ & $\begin{array}{l}\text { Observational/ } \\
\text { cross-sectional }\end{array}$ & 6 \\
\hline E10 & $\begin{array}{l}\text { Chemical production in electrocautery smoke by a } \\
\text { novel predictive model }{ }^{(26)}\end{array}$ & 2011 & Unreported & $\begin{array}{l}\text { Observational/ } \\
\text { cross-sectional }\end{array}$ & 6 \\
\hline E11 & $\begin{array}{l}\text { Harmful gases including carcinogens produced } \\
\text { during transurethral resection of the prostate and } \\
\text { vaporization }{ }^{(27)}\end{array}$ & 2010 & $\begin{array}{l}\text { Jeonju, South } \\
\text { Korea }\end{array}$ & $\begin{array}{l}\text { Observational/ } \\
\text { cross-sectional }\end{array}$ & 6 \\
\hline E12 & $\begin{array}{l}\text { Chemical composition of gases surgeons are exposed } \\
\text { to during endoscopic urological resections }{ }^{(28)}\end{array}$ & 2009 & Unreported & $\begin{array}{l}\text { Observational/ } \\
\text { cross-sectional }\end{array}$ & 6 \\
\hline E13 & $\begin{array}{l}\text { Chemical composition of smoke produced by high- } \\
\text { frequency electrosurgery }\end{array}$ & 2007 & Navan, Ireland & $\begin{array}{l}\text { Observational/ } \\
\text { cross-sectional }\end{array}$ & 6 \\
\hline E14 & $\begin{array}{l}\text { Smoke in the operating theater: an unregarded } \\
\text { source of danger }{ }^{(30)}\end{array}$ & 2004 & $\begin{array}{c}\text { Aarau, } \\
\text { Switzerland }\end{array}$ & $\begin{array}{l}\text { Observational/ } \\
\text { cross-sectional }\end{array}$ & 6 \\
\hline
\end{tabular}

Regarding the type of surgery in which the smoke was collected, there was a higher prevalence of transurethral resection of the prostate, followed by surgery of the digestive and abdominal tract, transurethral vaporization of the prostate, mastectomy, peritonectomy, transperitoneal nephrectomy, transurethral resection of the bladder, prostatectomy, mammoplasty and excision of warts and sinuses.

The total number of surgeries in which were collected smoke samples produced by electrocautery ranged from four to 40 . The minimum and maximum mean operative time was 53 minutes and 614 minutes, respectively.

As for the form of collection and analysis of the chemical compounds, in $50 \%$ of studies, a vacuum pump was used for the collection. Most studies (78.5\%) analyzed the chemical compounds by gas chromatography. Regarding the chemical compounds found, there was a predominance of naphthalene, toluene and benzene.

Chart 3 shows a summary of the primary studies according to objective, surgical type and mean surgical time, collection and analysis of compounds, and main results found. 
Chart 3 - Summary of the primary studies according to objective, surgical type and mean surgical time, collection and analysis of compounds, and main results (2004-2014) - Londrina, PR, Brazil, 2015.

\begin{tabular}{|c|c|c|c|c|}
\hline Study & Objective & $\begin{array}{l}\text { Surgical type and mean } \\
\text { surgical time }\end{array}$ & $\begin{array}{l}\text { Collection/analysis of } \\
\text { compounds }\end{array}$ & Main results \\
\hline $\mathrm{E} 1^{(3)}$ & $\begin{array}{l}\text { To investigate the concentration of } \\
\text { particle number and concentration of } \\
\text { PAH in the electrocautery smoke }\end{array}$ & $\begin{array}{l}\text { Mastectomy/ } \\
96.3 \text { minutes }\end{array}$ & $\begin{array}{l}\text { Collection carried } \\
\text { out by a special bag } \\
\text { (unreported type of bag)/ } \\
\text { gas chromatography }\end{array}$ & $\begin{array}{l}\text { Naphthalene was } \\
\text { the most abundant } \\
\text { compound } \\
\text { with maximum } \\
\text { concentration of } 1055 \\
\mathrm{ng} / \mathrm{m}^{3}\end{array}$ \\
\hline$E 2^{(20)}$ & $\begin{array}{l}\text { To correlate PAH levels with the } \\
\text { perioperative variables }\end{array}$ & $\begin{array}{l}\text { Peritonectomy/ } \\
614 \text { minutes }\end{array}$ & $\begin{array}{l}\text { Vacuum pump/gas } \\
\text { chromatography }\end{array}$ & $\begin{array}{l}\text { Naphthalene } \\
\text { had the highest } \\
\text { average maximum } \\
\text { concentration of } 178.66 \\
\mathrm{ng} / \mathrm{m}^{3}\end{array}$ \\
\hline $\mathrm{E}^{(5)}$ & $\begin{array}{l}\text { To investigate the composition of the } \\
\text { surgical smoke }\end{array}$ & $\begin{array}{l}\text { Laparoscopic colorectal } \\
\text { resection/ } \\
195.83 \text { minutes }\end{array}$ & $\begin{array}{l}\text { Collection occurred } \\
\text { through a polypropylene } \\
\text { bag connected to } \\
\text { a sterile gas tube/ } \\
\text { spectrometry }\end{array}$ & $\begin{array}{l}\text { Sevoflurane had } \\
\text { the highest average } \\
\text { concentration of } 110 \\
\text { ppm (parts per million) }\end{array}$ \\
\hline $\mathrm{E} 4^{(21)}$ & $\begin{array}{l}\text { To analyze the concentration } \\
\text { of volatile hydrocarbons in the } \\
\text { electrocautery smoke in laparoscopic } \\
\text { intra-abdominal surgeries compared } \\
\text { with cigarette smoke and the air of an } \\
\text { urban city }\end{array}$ & $\begin{array}{l}\text { Laparoscopic digestive } \\
\text { tract surgeries/ } \\
\text { unreported surgical time }\end{array}$ & $\begin{array}{l}200 \mathrm{ml} \text { of gas were } \\
\text { aspirated by the surgeon } \\
\text { of the epigastric region } \\
\text { at the end of surgery/gas } \\
\text { chromatography }\end{array}$ & $\begin{array}{l}\text { The maximum } \\
\text { concentration found in } \\
\text { the smoke was of } 9652 \\
\text { ppm (toluene) }\end{array}$ \\
\hline $\mathrm{E}^{(4)}$ & $\begin{array}{l}\text { To analyze the surgical smoke } \\
\text { generated by electrocautery }\end{array}$ & $\begin{array}{l}\text { Transperitoneal } \\
\text { laparoscopic } \\
\text { nephrectomy/135.5 } \\
\text { minutes }\end{array}$ & $\begin{array}{l}\text { A polypropylene bag was } \\
\text { used for collection/gas } \\
\text { chromatography }\end{array}$ & $\begin{array}{l}\text { Among the main } \\
\text { VOC, benzene was } \\
\text { the most abundant, } \\
\text { with a maximum } \\
\text { concentration of } 231 \\
\mu \mathrm{g} / \mathrm{m}^{3}\end{array}$ \\
\hline $\mathrm{E}^{(22)}$ & $\begin{array}{l}\text { To analyze the electrocautery smoke } \\
\text { composition in two types of surgeries }\end{array}$ & $\begin{array}{l}\text { Transurethral resection } \\
\text { of the prostate and } \\
\text { transurethral resection } \\
\text { of bladder tumors/ } \\
\text { unreported surgical time }\end{array}$ & $\begin{array}{l}\text { Vacuum gas pump } 0.05 \mathrm{~L} / \\
\text { gas chromatography }\end{array}$ & $\begin{array}{l}\text { Maximum } \\
\text { concentration of VOC } \\
\text { found: isobutylene } \\
(35869.31 \mu \mathrm{g} / \mathrm{g})\end{array}$ \\
\hline$E 7^{(23)}$ & $\begin{array}{l}\text { To quantify the potentially dangerous } \\
\text { chemical compounds produced by } \\
\text { electrocautery smoke }\end{array}$ & $\begin{array}{l}\text { Mastectomy/unreported } \\
\text { surgical time }\end{array}$ & $\begin{array}{l}\text { Vacuum pump/gas } \\
\text { chromatography }\end{array}$ & $\begin{array}{l}\text { Maximum } \\
\text { concentration of } \\
\text { toluene found }(5.50 \\
\left.\mathrm{mg} / \mathrm{m}^{3}\right)\end{array}$ \\
\hline $\mathrm{E}^{(24)}$ & $\begin{array}{l}\text { To analyze the composition of VOC in } \\
\text { the electrocautery smoke }\end{array}$ & $\begin{array}{l}\text { Digestive tract surgery/ } \\
\text { unreported surgical time }\end{array}$ & $\begin{array}{l}\text { Portable gas collector } \\
\text { ('hand-held Yankauer } \\
\text { Suction')/mass } \\
\text { spectrometry }\end{array}$ & $\begin{array}{l}\text { Among the identified } \\
\text { VOC was found } \\
\text { the maximum } \\
\text { concentration of } 0.69 \\
\text { ppm for 1,3-butadiene }\end{array}$ \\
\hline $\mathrm{E9}^{(25)}$ & $\begin{array}{l}\text { To compare the gases generated in } \\
\text { prostate surgeries }\end{array}$ & $\begin{array}{l}\text { Prostatectomy, } \\
\text { transurethral resection } \\
\text { and vaporization of } \\
\text { prostate/unreported } \\
\text { surgical time }\end{array}$ & $\begin{array}{l}\text { Vacuum pump/gas } \\
\text { chromatography }\end{array}$ & $\begin{array}{l}\text { Maximum } \\
\text { concentration found: } \\
\text { isobutylene ( } 30662.62 \\
\left.\mu \mathrm{g} / \mathrm{m}^{3}\right)\end{array}$ \\
\hline $\mathrm{E} 10^{(26)}$ & $\begin{array}{l}\text { To quantify the gases produced by } \\
\text { electrocautery smoke }\end{array}$ & $\begin{array}{l}\text { Mastectomy (119 min) } \\
\text { and abdominal surgery } \\
(143.3 \text { minutes })\end{array}$ & $\begin{array}{l}\text { Vacuum pump/gas } \\
\text { chromatography }\end{array}$ & $\begin{array}{l}\text { Maximum average } \\
\text { concentration found: } \\
0.463 \mathrm{mg} / \mathrm{m}^{3} \text { (toluene) }\end{array}$ \\
\hline $\mathrm{E} 11^{(27)}$ & $\begin{array}{l}\text { To determine the chemical } \\
\text { composition of the electrocautery } \\
\text { smoke }\end{array}$ & $\begin{array}{l}\text { Transurethral resection } \\
\text { and vaporization of } \\
\text { prostate/unreported } \\
\text { surgical time }\end{array}$ & $\begin{array}{l}\text { Vacuum pump/gas } \\
\text { chromatography }\end{array}$ & $\begin{array}{l}\text { Maximum } \\
\text { concentration found: } \\
1,3 \text {-butadiene ( } 8652.44 \\
\mu \mathrm{g} / \mathrm{g})\end{array}$ \\
\hline $\mathrm{E} 12^{(28)}$ & $\begin{array}{l}\text { To identify the potentially harmful } \\
\text { chemical components of the surgical } \\
\text { smoke }\end{array}$ & $\begin{array}{l}\text { Transurethral resection } \\
\text { and vaporization of } \\
\text { prostate/53 minutes }\end{array}$ & $\begin{array}{l}\text { Vacuum pump/gas } \\
\text { chromatography }\end{array}$ & $\begin{array}{l}\text { The maximum } \\
\text { concentration of VOC } \\
\text { found was } 18.8 \mu \mathrm{g} / \mathrm{m}^{3} \\
\text { or } 0.005 \mathrm{ppm} \text { (toluene) }\end{array}$ \\
\hline $\mathrm{E} 13^{(29)}$ & $\begin{array}{l}\text { To quantify the toxic compounds } \\
\text { present in the electrocautery smoke }\end{array}$ & $\begin{array}{l}\text { Excision of warts, sinus } \\
\text { surgery, and abdominal } \\
\text { surgery/unreported } \\
\text { surgical time }\end{array}$ & $\begin{array}{l}\text { Charcoal tubes } \\
\text { connected to a smoke } \\
\text { evacuation system/gas } \\
\text { chromatography }\end{array}$ & $\begin{array}{l}\text { The maximum } \\
\text { concentration of VOC } \\
\text { found was } 4.39 \mu \mathrm{g} / \mathrm{m}^{3} \\
\text { (toluene) }\end{array}$ \\
\hline
\end{tabular}

continued... 
...continuation

\begin{tabular}{|c|l|l|l|l|}
\hline Study & \multicolumn{1}{|c|}{ Objective } & $\begin{array}{c}\text { Surgical type and mean } \\
\text { surgical time }\end{array}$ & \multicolumn{1}{|c|}{$\begin{array}{c}\text { Collection/analysis of } \\
\text { compounds }\end{array}$} & \multicolumn{1}{c|}{ Main results } \\
\hline E14(30) & $\begin{array}{l}\text { To determine the composition } \\
\text { of gases and the respective } \\
\text { concentrations of electrocautery } \\
\text { smoke }\end{array}$ & $\begin{array}{l}\text { Mammoplasty/ } \\
\text { unreported surgical time }\end{array}$ & $\begin{array}{l}\text { Unreported collector } \\
\text { type/laser spectrometer }\end{array}$ & $\begin{array}{l}\text { Maximum } \\
\text { concentration of } \\
\text { VOC found: 17 ppm } \\
\text { (toluene) }\end{array}$ \\
\hline
\end{tabular}

In the case of electrocautery smoke composition, The studies were grouped into three categories, namely: $\mathrm{PAH}$, volatile compounds and VOC. Chart 4 presents these groupings taking into consideration that stud- ies E1 and E2 were grouped into the first category; the second category included the study E3; and in the third category were grouped the studies from E4 Until E14.

Chart 4 - Summary of the primary studies according to category and compounds found in the electrocautery smoke (2004-2014) Londrina, PR, Brazil, 2015.

\begin{tabular}{|c|c|c|}
\hline Study & Category & $\begin{array}{l}\text { Compounds found in the electrocautery } \\
\text { smoke }\end{array}$ \\
\hline$E 1^{(3)}$ and $E 2^{(20)}$ & First & $\mathrm{PAH}$ \\
\hline $\mathrm{E}^{(5)}$ & Second & Volatile compounds \\
\hline $\mathrm{E} 4^{(21)}, \mathrm{E} 5^{(4)}, \mathrm{E} 6^{(22)}, \mathrm{E} 7^{(23)}, \mathrm{E} 8^{(24)}, \mathrm{E} 9^{(25)}, \mathrm{E} 10^{(26)}, \mathrm{E} 11^{(27)}, \mathrm{E} 12^{(28)}, \mathrm{E} 13^{(29)}$ and $\mathrm{E} 14^{(30)}$ & Third & VOC \\
\hline
\end{tabular}

\section{DISCUSSION}

The results of this integrative literature review indicate a modest increase in scientific productions on the composition of electrocautery smoke and its effects on workers' health. In addition, all studies were international productions, that is, there is not any research on this subject in the Brazilian context yet.

The compounds identified in the first category refer to the $\mathrm{PAH}$, which were identified in studies $\mathrm{E} 1^{(3)}$ and $\mathrm{E} 2{ }^{(20)}$. The PAH is a broad class of compounds and hundreds of chemicals that can be released by the incomplete burning of charcoal, oil, gas, garbage or pyrolysis of organic substances such as tobacco. These organic compounds contain two or more aromatic rings composed of carbon $(\mathrm{C})$ and hydrogen $(\mathrm{H})^{(7,31)}$ atoms. It has also been reported that electrocautery smoke contains $\mathrm{PAH}$ among the substances and toxic gases generated by its use ${ }^{(8)}$.

PAH chemicals can be harmful to health because they have high carcinogenic potential, and cause effects on the skin, liver and immune system ${ }^{(7,31)}$. Several compounds, including benzo[a]anthracene, benzo[a]pyrene, benzo[b] fluoranthene, benzo[j]fluoranthene, benzo[k]fluoranthene, chrysene, dibenz[a,h]anthracene, and indeno[1,2,3-c,d] pyrene have caused tumors in animals when inhaled or during skin contact. They can also develop cancer in human beings ${ }^{(32)}$.

In the study $\mathrm{E} 1^{(3)}$ were collected 10 samples of smoke during mastectomy surgeries. The greatest quantities found in these samples were of naphthalene in the volatile state $\left(1055 \mathrm{ng} / \mathrm{m}^{3} \text { or } 0.001055 \mathrm{mg} / \mathrm{m}^{3}\right)^{(3)}$. Its levels did not exceed the recommendations of international agencies, which advise a limit of up to $50 \mathrm{mg} / \mathrm{m}^{3(33-34)}$.

In the study E2 were identified and quantified 16 different types of PAH during 40 peritonectomy surgeries ${ }^{(20)}$. As in the study E1, naphthalene ${ }^{(3)}$ was the most abundant, with a maximum average value of $178.66 \mathrm{ng} / \mathrm{m}^{3(20)}$. Its levels also did not exceed the limits recommended by an international agency ${ }^{(34)}$.

This brings us to disturbing reflections in case the exposure occurs in larger quantities and longer periods of time because the international agency ${ }^{(34)}$ does not determine the time of workers' exposure to naphthalene. Moreover, it is important to pay attention to the presence of this chemical compound, because the international agency classifies naphthalene as a possible human carcinogen ${ }^{(35)}$.

The second category included only the study $\mathrm{E} 3^{(5)}$. In this study many volatile compounds were found in the electrocautery smoke during laparoscopic colorectal resection surgeries ${ }^{(5)}$. Among them are methane, ethane, ethylene, hydrogen fluoride, carbon monoxide traces and the sevoflurane anesthetic. This anesthetic presented the most abundant average concentration (110 ppm) of all the mentioned compounds $\mathrm{s}^{(5)}$, exceeding the permitted limits of $2 \mathrm{ppm}^{(36)}$.

A study with rats found that long-term exposure to the sevoflurane volatile anesthetic affects fertility ${ }^{(37)}$. Note that the effects of long-term exposure to this anesthetic in human beings are still unknown ${ }^{(5)}$.

In the studies of the third category (E4 to E14) ${ }^{(4,21-30)}$, several gases were identified, but the $\mathrm{VOC}$ were the chemical compounds present in all articles. Therefore, the predominant VOC identified and quantified were the following: benzene $^{(4,21-22,28)}$, ethylbenzene ${ }^{(4,21,26,28-29)}$, toluene ${ }^{(4,21-23,26,28-30)}$, styrene $^{(4,21,26,28)}$ and butadiene $e^{(22,24-25,27,30)}$.

This diversity of compounds can be justified by the different types of surgeries in which were collected smoke samples, the body mass index of different patients, and the duration, and energy of electrocautery use because these factors can alter the compounds production ${ }^{(23,26)}$, increasing the risk of occupational exposure even more, since professionals can work in many surgical rooms and various surgi- 
cal procedures daily. The use of drugs as aspirin by patients and professionals involved in the surgery is a factor that can also influence the effect of VOC such as toluene in the human body ${ }^{(38)}$.

Benzene is highly hazardous to the health of workers, and considered a regular myelotoxic, leukemogenic, neurotoxic, carcinogenic and mutagenic, even at low concentrations. The repeated and prolonged occupational exposures may cause benzene poisoning and trigger various complications, including irritation of the ocular and respiratory mucous membranes, pulmonary edema, hematologic abnormalities, chromosomal alterations in lymphocytes and bone marrow cells, and toxic effects to the central nervous system depending on the amount absorbed, causing drowsiness, headache, tachycardia, convulsions, loss of consciousness and death ${ }^{(39)}$.

The benzene compound can also trigger onco-hematological diseases such as the non-Hodgkin's lymphoma ${ }^{(39)}$. It is classified by an international agency as a chemical substance with sufficient evidence of carcinogenic effect in humans ${ }^{(40)}$.

Ethylbenzene is another VOC identified in the primary studies of this integrative review. When present in high levels, even if for short periods, it can cause dizziness and irritation in the throat and eyes, and vertigo ${ }^{(41)}$. According to the international agency, this compound was classified as a possible human carcinogen ${ }^{(40)}$.

Toluene is also present in the electrocautery smoke and can affect the cardiovascular system and the nervous system. In low to moderate amounts, the occupational exposure can cause fatigue, mental confusion, memory loss, nausea, and lack of appetite. These symptoms usually cease with interruption of exposure ${ }^{(38)}$.

When the daily occupational exposure to toluene occurs in the long-term, it can cause loss of hearing, vision, muscle control and balance, as well as dizziness and unconsciousness. If exposure to this compound is not interrupted, it can cause permanent brain damage and even death. The combination of exposure to toluene and alcohol intake can affect the liver, and the combination of this compound with medications such as aspirin and paracetamol may increase the compound effects on the hearing ${ }^{(38)}$. By contrast, there is no published evidence on the carcinogenic effect of toluene $\mathrm{e}^{(38,40)}$.

With respect to styrene, it was classified as a possible human carcinogen ${ }^{(40)}$. The inhalation of high levels of this compound can cause central nervous system effects, including changes in the colors of vision, tiredness, decreased reaction time, and problems of concentration or balance ${ }^{(42)}$.

The 1,3-butadiene or butadiene, another VOC found in studies of the third category, is a highly flammable gas and for being heavier than air, may accumulate in closed and poorly ventilated environments ${ }^{(43)}$ such as the operating room.

In human beings, the inhalation of 1,3-butadiene in very high concentrations may result in effects on the central nervous system, including headache, somnolence, ataxia, loss of consciousness, coma, respiratory depression and death ${ }^{(43)}$. Furthermore, it was classified as a carcinogen for humans ${ }^{(40)}$.
In relation to the acceptable levels of VOC, the recommended acute inhalation (short time) for benzene is up to $0.09 \mathrm{ppm} ; 5 \mathrm{ppm}$ of ethylbenzene; $1 \mathrm{ppm}$ of toluene; $5 \mathrm{ppm}$ of styrene ${ }^{(44)}$; and $1 \mathrm{ppm}$ of butadiene or 1,3-butadiene ${ }^{(45)}$.

According to the international agency, the acceptable levels of VOC are given in ppm hence, when comparing the occupational limit values with the results of the third category of this review in ppm, were found changes in values, including the studies $\mathrm{E} 4^{(21)}$ and $\mathrm{E} 14^{(30)}$.

In the study $\mathrm{E} 4{ }^{(21)}$, in laparoscopic intra-abdominal surgeries, the levels of benzene and toluene exceeded the allowed limits. The maximum levels of toluene were 9.652 $\mathrm{ppm}^{(21)}$, and the limit is $1 \mathrm{ppm}^{(44)}$. The values of toluene found were higher in the electrocautery smoke when compared with cigarette smoke and the air of an urban city ${ }^{(21)}$.

Furthermore, in the study E14 ${ }^{(30)}$ of the third category, during mammoplasties, were found concentrations of 1.5 ppm for 1,3-butadiene and $17 \mathrm{ppm}$ for toluene ${ }^{(30)}$. These levels were higher than allowed and the recommendation for these two compounds is $1 \mathrm{ppm}^{(44-45)}$.

The toxic effects of the chemical compounds mentioned in this integrative review refer to the ideas and concerns in relation to surgical center workers, including the nursing, surgical and anesthetic teams, which are constantly exposed to electrocautery smoke in their working environment. They face the risk of developing respiratory symptoms, several cancers, genetic mutation, and depression of the central nervous system. There are also the effects that have not been identified in humans, but proven in animal experiments ${ }^{(38-39,41-43)}$.

The amount of compounds generated by the use of electrocautery is noteworthy, as within five minutes of the beginning of its use the amount of particles increases significantly in the operating room, going from about 60,000 particles $/ \mathrm{m}^{3}$ to more than 1 million particles $/ \mathrm{m}^{3(46)}$. Another study showed that the cauterization of $1 \mathrm{~g}$ of tissue releases the same degree of mutagenic toxins as if the person smoked three to six cigarettes per day ${ }^{(6)}$, increasing the risk for smoking workers even more.

Therefore, it is necessary to install suitable fans and exhaust fans for operating rooms in order to protect the surgical team workers that face smoke inhalation ${ }^{(9-10)}$. These air extraction systems can reduce the number of germs and particles, the generated heat, and any hazardous substance emitted ${ }^{(2)}$. Furthermore, the use of respiratory protective equipment (N-95 mask) is able to protect workers and filter at least $95 \%$ of microorganisms in the form of aerosols, as well as non-biological particles such as the electrocautery smoke ${ }^{(10)}$.

Therefore, based on the critical analysis of studies and recognizing that the chemical compounds present in the electrocautery smoke are harmful to the health of workers exposed to this risk, we suggest the conduction of experimental studies to identify cause and effect in the development of occupational diseases, as well as the conduction of protocols to support working conditions improvements in the Brazilian perspective and reality. Moreover, to alert the health workers and managers about the risks to which the intraoperative team is exposed. 
Although the objective of this review has been achieved, it has limitations because the studies did not show methodologies characterized by the levels 2 and 3 of scientific evidence, but only level 6 .

\section{CONCLUSION}

From the analyzed studies it is possible to confirm the presence of $\mathrm{PAH}$, various volatile compounds, and VOC in the electrocautery smoke, both in acceptable occupational levels as in high and harmful levels for surgical team workers. There is also scientific evidence that electrocautery smoke and its inhaling constitute potential chemical risks to the health of workers involved in the surgery due to the presence of toxic chemicals in this smoke.

The lack of Brazilian studies on the smoke produced by electrocautery stands out, allowing the conclusion that there are no national protocols for workers on the prevention of risks and harms caused by electrocautery smoke. Health managers and workers need to be aware of this occupational hazard and the essential preventive measures for health workers of the intraoperative team.

\section{RESUMO}

Objetivo: Identificar a composição da fumaça produzida pelo uso do bisturi elétrico durante o ato cirúrgico. Método: Revisão integrativa na qual a busca dos estudos primários foi realizada nas bases de dados US National Library of Medicine National Institutes of Health, Cumulative Index to Nursing and Allied Health Literature e Literatura Latino-Americana e do Caribe em Ciências da Saúde, abrangendo estudos publicados entre 2004 e 2014. Resultados: A amostra final foi composta por 14 estudos, agrupados em três categorias, hidrocarbonetos policíclicos aromáticos, compostos voláteis e compostos orgânicos voláteis. Conclusão: Há evidências científicas de que a fumaça do bisturi elétrico possui compostos voláteis tóxicos, cancerígenos e mutagênicos, e sua inalação constitui-se em riscos químicos potenciais à saúde dos trabalhadores que estão envolvidos no ato cirúrgico.

\section{DESCRITORES}

Exposição Ocupacional; Riscos Ocupacionais; Saúde do Trabalhador; Eletrocirurgia; Fumaça; Revisão.

\section{RESUMEN}

Objetivo: Identificar la composición del humo producido por el empleo del bisturí eléctrico durante el acto quirúrgico. Método: Revisión integradora en la que la búsqueda de los estudios primarios fue llevada a cabo en las bases de datos US National Library of Medicine National Institutes of Health, Cumulative Index to Nursing and Allied Health Literature y Literatura Latinoamericana y del Caribe en Ciencias de la Salud, abarcando estudios publicados entre 2004 y 2014. Resultados: La muestra estuvo compuesta de 14 estudios, agrupados en tres categorías: hidrocarburos policíclicos aromáticos, compuestos volátiles y compuestos orgánicos volátiles. Conclusión: Hay evidencias científicas de que el humo del bisturí eléctrico tiene compuestos volátiles tóxicos, cancerígenos y mutagénicos, y su inhalación se constituye en riesgos químicos potenciales a la salud de los trabajadores que están involucrados en el acto quirúrgico.

\section{DESCRIPTORES}

Exposición Profesional; Riesgos Laborales; Salud Laboral; Electrocirugia; Humo; Revisión.

\section{REFERENCES}

1. Navarro-Meza MC, González-Baltazar R, Aldrete-Rodríguez MG, Carmona-Navarro DH, López-Cardona MG. Síntomas respiratorios causados por el uso del electrocauterio en médicos en formación quirúrgica de un hospital de México. Rev Peru Med Exp Salud Pública. 2013;30(1):41-4

2. Eickmann IU, Falcy M, Fokuhl I, Rüegger M, Bloch M, Merz B; International Social Security. International Section of the ISSA on Prevention of Occupational Risks in Health Services. Surgical smoke: risks and preventive measures. Geneva: ISSA; 2012.

3. Tseng HS, Liu SP, Uang SN, Yang LR, Lee SC, Liu YJ, et al. Cancer risk of incremental exposure to polycyclic aromatic hydrocarbons in electrocautery smoke for mastectomy personnel. World J Surg Oncol. 2014;12:31.

4. Choi SH, Kwon TG, Chung SK, Kim TH. Surgical smoke may be a biohazard to surgeons performing laparoscopic surgery. Surg Endosc. 2014;28(8):2374-80.

5. Gianella M, Hahnloser D, Rey JM, Sigrist MW. Quantitative chemical analysis of surgical smoke generated during laparoscopic surgery with a vessel-sealing device. Surg Innov. 2014;21(2):170-9.

6. Tomita Y, Mihashi S, Nagata K, Ueda S, Fujiki M, Hirano M, et al. Mutagenicity of smoke condensates induced by CO2-laser irradiation and electrocauterization. Mutat Res. 1981;89(2):145-9.

7. United States of America. Department of Health and Human Services, Agency for Toxic Substances and Disease Registry. Polycyclic Aromatic Hydrocarbons (PAHs) [Internet]. Atlanta; 2011 [cited 2014 July 2]. Available from: http://www.atsdr.cdc.gov/substances/ toxsubstance.asp?toxid=25

8. United States of America. United States Departmente of Labor, Occupacional Safety \& Health Administration. Laser/electrosurgery plume [Internet]. Washington: OSHA; 2008 [cited 2014 Aug. 4]. Available from: https://www.osha.gov/SLTC/laserelectrosurgeryplume/

9. Association of Perioperative Registered Nurses. Recommended Practices Committee. Recommended practices for electrosurgery. AORN J. 2005;81(3):616-8, 621-6, 629-32. 
10. Association of Perioperative Registered Nurses. RP Summary: recommended practices for electrosurgery. AORN J. 2012;95(3):388-90.

11. Brasil. Ministério da Saúde; Agência Nacional de Vigilância Sanitária. Cartilha de proteção respiratória contra agentes biológicos para trabalhadores de saúde [Internet]. Brasília: ANVISA; 2009 [citado 2014 out. 2]. Disponível em: http://portal.anvisa.gov.br/wps/wcm/conn ect/48b0da00474588939240d63fbc4c6735/tecnovigilanca_cartilha_protecao_respiratoria.pdf?MOD=AJPERES

12. Bałazy A, Toivola M, Adhikari A, Sivasubramani SK, Reponen T, Grinshpun SA. Do N95 respirators provide 95\% protection level against airborne viruses, and how adequate are surgical masks? Am J Infect Control. 2006;34(2):51-7.

13. Benson SM, Novak DA, Ogg MJ. Proper use of surgical N95 respirators and surgical masks in the OR. AORN J. 2013;97(4):457-67.

14. Ball K. Surgical smoke evacuation guidelines: compliance among perioperative nurses. AORN J. 2010;92(2):1-23.

15. Bibb SC, Wanzer LJ. Determining the evidence in the perioperative environment: standardizing research process tools for conducting the integrative literature review. Perioper Nurs Clin. 2008;3(1):1-17.

16. Galvão CM, Mendes KDS, Silveira RCCP. Revisão integrativa: método de revisão para sintetizar as evidências disponíveis na literatura. In: Brevidelli MM, Sertório SCM. Trabalho de conclusão de curso: guia prático para docentes e alunos da área da saúde. São Paulo: látrica; 2010. p. 105-26.

17. Melnyk BM, Fineout-Overholt E. Evidence-based practice in nursing \& healthcare: a guide to best practice. Philadelphia: Lippincot Williams \& Wilkins; 2005. Making the case for evidence-based practice; p. 3-24.

18. Ursi ES, Galvão CM. Prevenção de lesões de pele no perioperatório: revisão integrativa da literatura. Rev Lat Am Enfermagem. 2006;14(1):124-31.

19. Hulley SB, Cummings SR, Browner WS, Grady DG, Newman TB. Delineando a pesquisa clínica: uma abordagem epidemiológica. $3^{a}$ ed. Porto Alegre: Artmed; 2008.

20. Andréasson SN, Mahteme H, Sahlberg B, Anundi H. Polycyclic aromatic hydrocarbons in electrocauterymoke during peritonectomy procedures. J Environ Public Health. 2012;2012:929053.

21. Fitzgerald JE, Malik M, Ahmed I. A single-blind controlled study of electrocautery and ultrasonic scalpel smoke plumes in laparoscopic surgery. Surg Endosc. 2012;26(2):337-42.

22. Zhao C, Kim MK, Kim HJ, Lee SK, Chung YJ, Park JK. Comparative safety analysis of surgical smoke from transurethral resection of the bladder tumors and transurethral resection of the prostate. Urology. 2013;82(3):744.e9-744.e14.

23. Lin YW, Fan SZ, Chang KH, Huang CS, Tang CS. A novel inspection protocol to detect volatile compounds in breast surgery electrocautery smoke. J Formos Med Assoc. 2010;109(7):511-6.

24. Moot AR, Ledingham KM, Wilson PF, Senthilmohan ST, Lewis DR, Roake J, et al. Composition of volatile organic compounds in diathermy plume as detected by selected ion flow tube mass spectrometry. ANZ J Surg. 2007;77(1-2):20-3.

25. Park SC, Lee SK, Han SH, Chung YJ, Park JK. Comparison of harmful gases produced during GreenLight High-Performance System laser prostatectomy and transurethral resection of the prostate. Urology. 2012;79(5):1118-24.

26. Wu YC, Tang CS, Huang HY, Liu CH, Chen YL, Chen DR, et al. Chemical production in electrocautery smoke by a novel predictive model. Eur Surg Res. 2011;46(2):102-7.

27. Chung YJ, Lee SK, Han SH, Zhao C, Kim MK, Park SC, et al. Harmful gases including carcinogens produced during transurethral resection of the prostate and vaporization. Int J Urol. 2010;17(11):944-9.

28. Weston R, Stephenson RN, Kutarski PW, Parr NJ. Chemical composition of gases surgeons are exposed to during endoscopic urological resections. Urology. 2009;74(5):1152-4.

29. Al Sahaf OS, Vega-Carrascal I, Cunningham FO, McGrath JP, Bloomfield FJ. Chemical composition of smoke produced by high-frequency electrosurgery. Ir J Med Sci. 2007;176(3):229-32.

30. Hollmann R, Hort CE, Kammer E, Naegele M, Sigrist MW, Meuli-Simmen C. Smoke in the operating theater: an unregarded source of danger. Plast Reconstr Surg. 2004;114(2):458-63.

31. World Health Organization. International Programme on Chemical Safety. Selected non-heterocyclic polycyclic aromatic hydrocarbons. Geneva: WHO; 1988.

32. United States of America. Department of Health and Human Services. Agency for Toxic Substances and Disease Registry. Toxicological profile for Polycyclic Aromatic Hydrocarbons (PAHs) [Internet]. Atlanta; 1995 [cited 2014 July 2]. Available from: http://www.atsdr.cdc. gov/toxprofiles/tp69.pdf

33. United States of America. Department of Health and Human Services. Agency for Toxic Substances and Disease Registry. Case studies in environmental medicine. toxicity of Polycyclic Aromatic Hydrocarbons (PAHs) [Internet]. Atlanta; 2009 [cited 2014 July 03]. Available from: http://www.atsdr.cdc.gov/toxprofiles/tp69.pdf

34. United States of America. Department of Labor. Occupational Safety \& Health Administration. Chemical Sampling Information. Naphthalene [Internet]. Washington: OSHA; 2012 [cited 2014 Sept. 31]. Available from: https://www.osha.gov/dts/chemicalsampling/ data/CH_255800.html

35. World Health Organization; International Agency for Research on Cancer. Monographs on the evaluation of carcinogenic risks to humans [Internet]. Lyon: IARC Press; 2002 [cited 2014 Sept. 31]. Available from: http://monographs.iarc.fr/ENG/Monographs/vol82/mono82.pdf

36. Center for Disease Control and Prevention; National Institute for Occupational Safety and Health. Criteria for a Recommended Standard. Occupational exposure to waste anesthetic gases and vapors [Internet]. Washington: NIOSH; 1977 [cited 2014 Oct 02]. Available from: http://www.cdc.gov/niosh/docs/1970/77-140.html

37. Ceyhan A, Cincik M, Bedir S, Ustun H, Dagli G, Kalender H. Effects of exposure to new inhalational anesthetics on spermatogenesis and sperm morphology in rabbits. Arch Androl. 2005;51(4):305-15. 
38. United States of America. Department of Health and Human Services; Agency for Toxic Substances and Disease Registry. Toxicological profile for toluene [Internet]. Atlanta: US Department of Health and Human Services; 2000 [cited 2014 Oct 3]. Available from: http:// www.atsdr.cdc.gov/toxprofiles/tp56.pdf

39. Brasil. Ministério da Saúde. Portaria n. 776, de 28 de abril de 2004. Dispõe sobre a regulamentação dos procedimentos relativos à vigilância da saúde dos trabalhadores expostos ao benzeno, e dá outras providências [Internet]. Brasília; 2004[citado 2014 out. 03]. Disponível em: http://dtr2001.saude.gov.br/sas/PORTARIAS/Port2004/GM/GM-776.htm

40. World Health Organization; International Agency for Research on Cancer. Agents classified by the IARC monographs [Internet]. Lyon: IARC; 2014 [cited 2014 Oct 0 6]. Available from: http://monographs.iarc.fr/ENG/Classification/ClassificationsGroupOrder.pdf

41. United States of America. Department of Health and Human Services; Agency for Toxic Substances and Disease Registry. Toxicological profile for ethylbenzene (Draft for Public Comment) [Internet]. Atlanta; 2010 [cited 2014 Oct. 10]. Available from: http://www.atsdr.cdc. gov/ToxProfiles/tp.asp?id=383\&tid=66

42. United States of America. Department of Health and Human Services; Agency for Toxic Substances and Disease Registry. Toxicological profile for styrene [Internet]. Atlanta; 2010 [cited 2014 Oct. 5]. Available from: http://www.atsdr.cdc.gov/ToxProfiles/tp53.pdf

43. United States of America. Department of Health and Human Services; Agency for Toxic Substances and Disease Registry. Toxicological profile for 1,3-Butadiene [Internet]. Atlanta; 2012 [cited 2014 Oct 06]. Available from: http://www.atsdr.cdc.gov/toxprofiles/tp.asp?id=459\&tid=81

44. United States of America. Department of Health and Human Services; Agency for Toxic Substances and Disease Registry. Minimal Risk Levels (MRLs) list [Internet]. Atlanta; 2013 [cited 2014 Oct 16]. Available from: http://www.atsdr.cdc.gov/mrls/mrllist.asp\#29tag

45. United States of America. Department of Labor; Occupational Safety \& Health Administration. Chemical Sampling Information. Butadiene [Internet]. Washington: OSHA; 2012 [cited 2014 Nov. 02]. Available from: https://www.osha.gov/dts/chemicalsampling/data/CH_222100.html

46. Brandon HJ, Young VL. Characterization and removal of electrosurgical smoke. Surg Serv Manag. 1997;3(3):14-16. 